\title{
ПОВЕСТЬ БЫВШЕГО ПЕДОЛОГА О ПОДРОСТКАХ И ВОЕННОМ ВРЕМЕНИ
}

\author{
Н. Ю. Стоюхина
}

Нижегородский государственный университет им. Н. И. Лобачевского

Аннотация: В статье рассказывается о детской книге, написанной бывшим педологом И. А. Печерниковой, о проблемах подростков в годы Великой Отечественной войны (1951). Одновременно описываются задачи советской педагогики и психологии военного периода.

Ключевые слова: коммунистическое воспитание; Великая Отече-ственная война; советская психология; история психологии; И. А. Печер-никова; педология

\section{THE STORY OF A FORMER PAEDOLOGIST ABOUT ADOLESCENTS AND WARTIME}

\author{
N. Yu. Stoyukhina \\ Lobachevsky State University of Nizhny Novgorod
}

Abstract: The article describes a children's book written by the former paedologist I. A. Pechernikova on the problems of adolescents during the years of the Great Patriotic War. At the same time, it describes the tasks faced by Soviet pedagogy and psychology of the war period.

Keywords: communist education; Great Patriotic War; Soviet psychology; history of psychology; I. A. Pechernikova; paedology

В 1951 г. вышла книги Ирины Печерниковой «Подростки. Педагогическая повесть». Она не стала ярким событием в советской детской литературе, но тиражи были по нынешнему времени впечатляющими: 1951 г. - 1-е издание - 30000 экз., 1955 г. - 5-е издание - 200000, 1960 г. - 6-е издание - 100000... Она была переведена на китайский, польский, венгерский, чешский, немецкий, румынский, болгарский языки, а также на некоторые языки народов СССР.

Книга сопровождалась справкой об авторе Ирине Алексеевне Печерниковой:

Родилась И. А. Печерникова в 1909 г. в селе Заинске Татарской АССР. Вскоре ее семья переехала в Юрюзань Челябинской области.

Училась И. Печерникова в средней школе с педагогическим уклоном в городе Уфе. В 1931 г. окончила Ленинградский педагогический институт имени Герцена. В течение 15 лет состояла в комсомоле, из них семь лет 
была секретарем первичных комсомольских организаций. В 1939 г. И. Печерникова вступила в коммунистическую партию.

Первая книга автора - «Учительница-орденоносец Т. И. Бабайкина» - вышла в 1939 г. в г. Горьком, где И. Печерникова работала преподавателем областного института усовершенствования учителей, а затем директором областного Дворца пионеров имени В. П. Чкалова. Успешно защитила диссертацию на тему «Трудовое воспитание школьников в семье» на соискание ученой степени кандидата педагогических наук.

С 1944 г. И. Печерникова является старшим научным сотрудником Института теории и истории педагогики Академии педагогических наук РСФСР.

И. Печерникова - автор нескольких десятков работ по актуальным вопросам коммунистического воспитания детей. Массовыми тиражами вышли в свет ее книги и брошюры: «Родителям о пионерской организации» (издательство АПН РСФСР), «Детский труд в семье как средство коммунистического воспитания» (издательство «Правда»), «Поощрения и наказания детей в семье» (Учпедгиз), «Воспитание дисциплинированности подростков в семье» (издательство АПН РСФСР) и другие.

В конце 1959 г. в Горьковском издательстве вышла новая педагогическая повесть Ирины Печерниковой - «Ее любовь». В настоящее время она работает над второй частью этой повести и над докторской диссертацией о воспитании у учащихся коммунистического отношения к труду (Печерникова, 1960: 332).

В справке много неточностей, непонятно, например, чем занималась Печерникова после окончания Ленинградского педагогического института, с 1931 г. по 1939 г., кроме того, что была комсомолкой, а была она активным педологом в школьном секторе Нижегородского (Горьковского) Крайоно, о чем остались следы в виде статей в местной периодической печати.

В своих первых обнаруженных нами статьях двадцатипятилетняя Ирина Алексеевна, обращаясь к учителям как педагог-дефектолог, предлагает выявить детей, страдающих недостатками речи и организовать систематическую работу с детьми-логопатами, обещая регулярно печатать методические указания по исправлению каждой разновидности речевых дефектов (Орловский, Печерникова, 1933), рассказывает о проверочных испытаниях по математике и порядке их проведения (Печерникова, 1934ab). Позже, будучи заведующей Краевой педологической лаборатории при Горьковском институте политехнической школы, много консультирует школьных работников, систематически выступает с докладами на педологические темы «0 трудных детях», «Педологический анализ проверочных испытаний», «Ра- 
Научные труды Московского гуманитарного университета

2019 № 1

циональная организация бюджета времени учащихся» и т. д., ведет кружки для родителей и пр. (Хроника, 1934).

В 1935 г. выходят ее статьи с обзорами педологический деятельности: «Горьковский край значительно отстал в отношении развертывания педологической работы от других краев РСФСР. У нас нет ни одного педологического районного кабинета и всего при четырех образцовых школах г. Горького имеются педологи. Краевая педологическая лаборатория при Горьковском институте политехнической школы была организована всего год назад и является не столько организационно-методологическим и научным центром, сколько практическим учреждением, проводящим непосредственную работу в школе» и дальше рассказывает о тех разделах, по которым проходит работа лаборатории: педологическая консультация для детей, педологическая пропаганда среди родителей, педологическая пропаганда среди учительства, научно-исследовательская работа (Печерникова, 1935a: 72; см. также: Печерникова, 1935b).

В 1936 г., перед самым Постановлением ЦК ВКП (б) «0 педологических извращениях в системе Наркомпросов» Ирина Алексеевна, критически оценивая практику проведения проверочных испытаний 1935 г., анализирует ошибки и трудности, одобряет запрет Совнаркомом СССР и ЦК ВКП(б) «существующую неправильную практику индивидуальных вопросников» ${ }^{1}$, когда учитель заранее намечает отдельно для каждого учащегося вопросы, соответственно подготавливая ученика к ответам на вопросы (Печерникова, 1936b).

В общем, Ирина Печерникова встретила драматичный для всех педологов Советского Союза 1936 г. деятельной, грамотной, активной двадцатисемилетней девушкой.

После Постановления от 4 июля 1936 г. советские педологи начали каяться, критиковать друг друга (на самом деле - доносить и топить) и себя. Не были исключением и горьковские педологи, чью лабораторию закрыли, вероятно, сразу же. Вчерашние коллеги Печерниковой Э. Моносзон и Б. Орловский писали:

«Своим невежественным вмешательством в область обучения и воспитания детей педологическая лаборатория вредила педагогике, нанесла огромный ущерб школам нашего края. “Педологической лабораторией” широко практиковалась осужденная Центральным Комитетом партии система обследований школьников. За один только 1935-

${ }^{1}$ Постановление СНК СССР и ЦК ВКП(б) от 3 сентября 1935 г. «Об организации учебной работы и внутреннем распорядке в начальной, неполной средней и средней школе». 
1936 учебный год такого рода “обследованиям” было подвергнуто более тысячи детей. Педологи работу вели оторванно от учителей, от жизни школы, они видели ребенка 1-2 раза в обстановке лаборатории, беседы свои они вели формально, по стандартной схеме и ничего не могли дать полезного, кроме трафаретных, никому не нужных советов» (Моносзон, Орловский, 1936: 2).

И сразу же - «педологическая лаборатория» и «обследование» ставится в кавычки, вроде как авторы статьи засомневались: была ли это настоящая педологическая лаборатория и обследование или «так называемые»... Моносзон и Орловский вспоминают лженаучные «труды» своих коллег-педологов, среди которых «Опыт педологического анализа проверочных испытаний в школе» И. Печерниковой:

«Пользуясь анкетами, она "изучала" психическое состояние ученика и пыталась делать на основании этих анкет “научные” выводы, применяя антинаучную классификацию учащихся по типам - в зависимости от умственного развития, от характера психического реагирования. Педологические извращения И.А. Печерниковой далеко не исчерпываются этим. В момент дискуссии, развернувшейся по вопросам педологии, она резко встала на сторону “столпов" педологии и защищала их лженаучные положения» (там же).

На статью быстро ответил руководитель всей научной работой Горьковской педологической лаборатории профессор Горьковского педагогического института С. М. Василейский. Ответил воинственно, взяв под защиту своих сотрудников (в том числе - Печерникову) и выдвинув встречное обвинение Б. Орловскому (Василейский, 1936). Сама же Ирина Алексеевна смогла «реабилитироваться» декабрьской статьей, где осудила «педологическое судилище», «педологические издевательства», «суровые приговоры» своих недавних коллег-педологов, и вообще - практику обучения в специальных вспомогательных школах большинства детей с «умственной отсталостью», которые могут хорошо учится в обычных школах по полной программе (Печерникова, 1936b).

Потом Ирина Алексеевна работала в Институте усовершенствования учителей, директором Дворца пионеров, защитила кандидатскую диссертацию по педагогике «Трудовое воспитание школьников в семье», в 1944 г. перешла на работу в Институт теории и истории педагогики АПН РСФСР старшим научным сотрудником и стала писать книги. Список изданных ее книг насчитывает около двух десятков названий — от «Учительница-орденоносец Т. И. Бабайкина» (1939) и методических пособий вроде «Трудовое воспитание школьника в семье» (1954) до многократное переизданные «Вечный пример» и «Величие души» - книги о семьях К. Маркса и В. И. Ленина, где впервые были осуществлены на практике принципы коммунистического воспитания. 
Научные труды Московского гуманитарного университета 2019 № 1

Педолог как писатель - такое бывает нечасто, поэтому нас заинтересовала педагогическая повесть «Подростки». Конечно, ее популярность не идет ни в какое сравнение с повестью Н. Носова «Витя Малеев в школе и дома» (см.: Майофис, 2017: Электр. ресурс), и время в «Подростках» 一 примерно 1944 г., а не послевоенное, как у Носова, но возраст школьников и проблемы - сходные. И, конечно же, было интересно посмотреть, как использовала бывший педолог свои знания по возрастной и педагогической психологии в своем художественном творчестве, как отразила психологические проблемы отечественной психологии, решаемые во время войны.

Итак, 1944 г., Москва. Врач Надежда Андреевна сильно занята в госпитале, ей некогда заниматься с детьми-школьниками, муж воюет, и она отправляет их (сына Володю и дочь Галю) в районный городок Горьковской области к свекрови. Бабушка, любя внуков, заботится только о том, чтобы внукам было сытно, а Володя, ученик 7 класса, скоро оказывается в числе неуспевающих, врет, прогуливает. За постоянное вранье и подделку отметок в табеле его исключают из пионеров, и мать решает вернуть детей в Москву, т. к. бабушка не справляется с воспитанием.

В новой школе, часто общаясь с талантливыми и проницательными педагогами, Надежда Андреевна постепенно прозревает: оказывается, чтобы воспитать детей, необходимо посвящать им много времени, интересоваться их делами, разговаривать с ними (она часто забывает про это, а, вспомнив, корит себя, автор часто повторяет «ей в голову не приходило...»), и, конечно, постоянно советоваться с учителями. Родители учеников на родительских собраниях, на педсоветах, в приватных разговорах говорят друг с другом и с педагогами исключительно о трудовом и коммунистическом воспитании своих детей, ругают себя за ошибки, за мягкость («Ребятам надо почаще напоминать, что, дескать, не гонитесь за легоньким, а то из вас жидкие люди получатся. Но мало говорить! <...> Надо нам, родителям, быть твердыми. Раз сказал сыну - делай по утрам гимнастику, или за уроки вовремя садись, или работай по хозяйству, так уж не отступай, не делай поблажки. Может, парню не хочется, а пусть делает. Так день за днем и привыкнет. Тогда и в характере сила будет. Приходится признать: не умеем мы каждодневно добиваться, чтобы ребята с охотой делали все, что надо», — говорит дедушка одного ученика (Печерникова, 1960: 39)).

В тексте много нелепостей, так, во время войны часто назначаются родительские собрания, которые так хороши, что директор школы из далекого Якутска приезжает в московскую школу, чтобы познакомиться с опытом коллег по их проведению; выпускники школы прошлых лет, воюющие на разных фронтах, бросают свои боевые участки и приезжают в родную школу на слет выпускников и т. д. 
В тексте очевидны психологические и психолого-педагогические концепты: воля и развитие волевых свойств характера, самовоспитание, сознательность в усвоении знаний, трудовое и патриотическое воспитание, учение И. П. Павлова, И. М. Сеченова, теории (педолога) Е. А. Аркина, воплощенные в: а) методических размышлениях о взаимодействии школа-родители в коммунистическом воспитании при руководящей роли партии; б) педологическом прошлом автора с осуждением своей прошлой деятельности и деятельности коллег; в) самовоспитании воли.

Идея широкого привлечения родителей к воспитанию детей возникла еще у педологов, когда они занимались работой культурно-просветительного характера, внедряя в массы основные педологические знания. В мае 1931 г. в Ленинском районе Москвы на первой рабочей конференции по вопросам педологии была сделана попытка установить непосредственный контакт между педологами как исполнителями определенного «социального заказа», с одной стороны, и рабочим классом как социальным заказчиком советской педологии с другой. При обсуждении вопроса педолого-родительского взаимодействия рабочие говорили: «...Мы, родители, мало помогаем педагогам. В школе ребенок находится в одной обстановке, а дома в совершенно другой... В этом отношении самому рабочему населению надо подтянуться, чтобы обеспечить подлинно коммунистическое воспитание детей» (Соколов, 1931: 75).

После закрытия педологии вопрос об участии школы, семьи и общественности в воспитании детей обсуждался на коллегии Наркомпроса РСФСР 9 марта 1940 г. «В период завершения построения бесклассового коммунистического общества дело воспитания детей более, чем когда-либо, становится делом не только школы и семьи, но и все советской общественности. ... Родители многомиллионной армии школьников проявляют в последнее время особый интерес к работе школы и к общим вопросам воспитания детей. ... В стране поднимается, растет и ширится подлинное народное движение за коммунистическое воспитание детей и за оказание действительной помощи школе» (Из протокола..., 2017: 225). Коллегия рекомендовала расширять сеть родительских университетов и лекториев, проводить в них, помимо лекций, экскурсии в детские учреждения, на выставки детского творчества, демонстрировать кинофильмы на педагогические темы, организовывать выставки по отдельным вопросам воспитания детей, педагогические консультации, т. е. активизировать работу школ с родителями, шире освещать вопросы воспитания через радио и периодическую печать.

Педологический background И. А. Печерниковой просвечивает в словах и речах героев повести. Так, мама подростка, врач, думает о сложном возрасте своего сына: «...Это период полового созревания. Но она, врач, хорошо 
Научные труды Московского гуманитарного университета

2019 № 1

знала, что если дети в этом возрасте регулярно занимаются физкультурой, строго выполняют режим дня, и, главное, занимаются физическим трудом, то их организм проявляет стойкость, в развитии нервной системы не происходит отклонений» (Печерникова, 1960: 54). Или же завметодкабинетом, она же - парторг, «женщина с ясными серыми глазами», говорит молодой коллеге: «Беда наша в том, что мы не всегда умеем предвидеть, следовательно, не знаем еще каких-то психологических законов движения души этих маленьких человечков...» (там же: 73), и обещает подобрать литературу по подростковому возрасту, оговаривая отнестись к ней критически; понятно, что речь идет о педологической литературе.

Позже ее молодая коллега, читая книги Е. А. Аркина ${ }^{1}$ (1873-1948) - известного педолога, чьи труды были хорошо известны в 1920-1930-е гг., критически отзывается о его работах в своем дневнике:

«Когда я прочитала статьи и главы из некоторых педагогических книг о подростках, то обиделась за наших ребят. Мне кажется, что во многих случаях авторы крайне переоценивают значение "возрастных особенностей” подростков. Например, в книге профессора Аркина говорится, что подросткам свойственны самоуверенность, развязность, за которыми скрывается робость: “Подросток часто и курить, и пить начинает, и даже дебоши готов устраивать все для того, чтобы поставить себя па равной ноге с окружающими его взрослыми, чтобы заставить считаться с ним как с равным и не смотреть на него как на малое дитя, нуждающееся в указке". Какое отношение имеет характеристика, которую дает профессор Аркин, к нашим советским подросткам, пионерам и комсомольцам? <..> Никто не будет спорить с тем, что подросткам нравится чувствовать себя взрослыми. Они становятся преданными друзьями старших, которые к ним относятся с полным уважением и доверием, как к равным. Но стремление показать себя взрослыми у наших подростков проявляется не в «склонности к вину и дебошам», а в страстном желании участвовать в жизни и труде советского наро-

${ }^{1}$ Как пишут биографы Е. А. Аркина, «наибольшую известность труды Ефима Ароновича получили в 20-30-е гг. XX в., когда страна испытывала острую потребность в подобной литературе. В 1936 г. указом ЦК ВКП(б) было выпущено постановление “О педологических извращениях в системе Наркомпросов”, что повлекло за собой изменения в педагогической науке и практике. В этот период Е. А. Аркин пересмотрел некоторые свои взгляды и признал педологические воззрения ошибочными, хотя ранее был ярым их сторонником. Ученый продолжал активную научно-педагогическую и просветительскую деятельность, выполнял обязанности консультанта по физическому воспитанию в Центральном научно-методическом дошкольном кабинете Наркомпроса, сотрудничал с Управлением по дошкольному воспитанию Министерства просвещения РСФСР» (Камолина, Федикович, 2017: Электр. ресурс). 
да. Вот это правило. <..> Нет, душевная жизнь подростков куда богаче, сложнее, политически активнее, чем это многие думают. Я не понимаю, почему в научной литературе так мало описаны характерные особенности именно советского подростка! Как будто все подростки на свете одинаковы, как будто ребята могут жить вне определенных социальных условий! А ведь очень важно нам, учителям, да и родителям тоже, видеть новое, особенное в характере и поведении наших советских школьников, пионеров и комсомольцев. Если мы не научимся видеть и понимать это новое, то не справимся со своими задачами. А задачи перед нами стоят величественные - воспитать людей, которые будут бороться за коммунизм и, наверное, будут жить при коммунизме» (Печерникова, 1960: 80).

Эта же молодая учительница излагает свой психолого-педагогический доклад в дневнике: здесь и критика «педагогических книжек о переходном возрасте» (после Постановления 1936 г. названия «педология», «педологический» использовали только в официальных резко критических статьях, в остальных случаях употребляли прилагательное «педагогический»), и цитирование педологических высказываний (естественно, без указания источников) - «сами эти биологические особенности изменяются и совершенствуются под влиянием воспитания», и ссылки на И. М. Сеченова и И. П. Павлова, и ода самовоспитанию. И снова замечания неназванным педологам от председателя родительского комитета, рабочего-новатора: «В книге о воспитании детей мне встретились рассуждения о том, что мальчики-подростки всецело поглощены собственными переживаниями, что это возраст настроений, что у подростков сплошь и рядом возникают нездоровые фантазии. Мне кажется, что все это чепуха. Фантазии и мечты у наших ребят вполне здоровые и реальные» (Печерникова, 1960: 92). Да и сама завметодкабинетом заявляет: «Сегодня правильно критиковали рассуждения профессора Аркина и его последователей. <..> У нас как-то вошло в моду нападать на ученых педагогов. У некоторых из них есть ошибки. Но почему мы, учителя, считаем правильным ожидать, что кто-то там наверху, в ученом мире, исследовал проблемы коммунистического воспитания детей, а потом преподносил нам готовые теоретические положения и практические рецепты. А где же наше творчество?» (там же: 95).

И, наконец, звучат главные слова этой книги - похвала педагогу-воспитателю: «Разумеется, биологические задатки, наследственность никак нельзя игнорировать, но ... под влиянием могущественной силы коммунистического воспитания совершенствуются и биологические особенности человека, прежде всего его высшая нервная деятельность. Все зависит от 
воспитателей, от их ума, мировоззрения, от их искусства. И нет сильнее и способнее тех воспитателей, которые владеют марксистско-ленинской теорией, которые в своей деятельности опираются на великое ленинское учение о коммунистическом воспитании» (там же: 96).

В повести подростки вместе с взрослыми увлечены мыслями о воспитании и самовоспитании воли, для чего автор показывает безвольное поведение главного героя:

«Володя сел за стол с твердым намерением хорошо подготовить уроки. <...> Володя открыл учебник по зоологии и стал его перелистывать. Что же задали? Сейчас посмотрим в дневнике. Но там не оказалось ни одной записи. <..> Ну хорошо, пока можно заняться решением задачи по алгебре. Он внимательно вчитался в ее текст. Задача оказалась трудной. Сидеть над ней придется очень долго. Лучше сделать ее потом, когда будут готовы устные уроки. По английскому языку, кажется, задали тридцатый параграф. Надо перевести текст на русский язык. <...> Володя поискал словарь, но тот, как назло, куда-то запропастился. <...> Лучше, пожалуй, заняться географией. Куда же девалась книга? <...> По истории его спрашивали только вчера и завтра, кончено, не спросят. Какой же смысл учить? Володе стало скучно. Надо немного поразмяться. А что, если пойти на каток?» (там же: 56).

Во время Великой отечественной войны психология и педагогика изменили тематику научно-исследовательских работ сучетом военной обстановки. «Предметом изучения были такие свойства характера, как патриотизм, “большевистская убежденность и принципиальность”, отвага, мужество и героизм, активность и инициативность, дисциплинированность и выносливость» (Кольцова, Олейник, 2006: 104; Доброхотов, 1944). «Попытки описать особенности волевой регуляции поведения и выделить критерии волевого поведения представлены в работах Н. Д. Левитова, К. Н. Корнилова, П. А. Рудика, В. А. Яковлева и др.» (Кольцова, Олейник, 2006: 105). К тому же, в учебниках психологии для средних школ, введенной с 1947 г., были отдельные главы об этом. Автор такого учебника К. Н. Корнилов утверждал, что задача рационального воспитания воли решается за счет выработки коммунистического мировоззрения, создания строго определенного правильного режима, установление правильных взаимоотношений с коллективом, выработка правильных положительных привычек, ознакомление с биографиями великих людей, занятия физкультурой и спортом (Корнилов, 1946: 122). Автор другого учебника Б. М. Теплов предлагал примерно такой же ассортимент условий воспитания воли: формирование мировоззрения, развитие общественных чувств и на этой основе - воспитание в себе чувства долга; овладение уменьем хотеть; не принимать решений неисполни- 
мых и не вооружаться намерениями, которые не будут осуществимы; образование привычки оценивать свои действия, осознавать их последствия, смотреть на них со стороны; постоянная тренировка себя в преодолении внутренних и внешних препятствий, постоянное упражнение волевого усилия (Теплов, 1951: 200).

Как пишет И. Кукулин, причиной такого повышенного интереса к проблематике саморегуляции именно после войны стала критическая ситуация в школе середины 1940-х гг., вызванная тем, что многие дети «пропустили несколько лет учебы из-за военных действий и эвакуации, уровень преподавания был низким, авторитет школы среди взрослых и детей упал. Учителей не хватало, а рассчитывать на помощь родителей было практически невозможно» (Кукулин, 2015: 167), и взрослым ничего не оставалось, как апеллировать к способности детей контролировать самих себя и направлять собственное поведение.

В учебнике Б. М. Теплова есть фраза, в которую укладывается все содержание повести: «советские школьники воспитывают свою волю не в порядке индивидуального самосовершенствования, а как члены коллектива, стремящегося вместе со всем советским народом к общей великой цели» (Теплов, 1951: 200).

В «общем унылом контексте школьной повести» (Майофис, 2017: Электр. ресурс) повесть И. А. Печерниковой «Подростки» продержалась десять лет; наверное, кому-то были интересны назидательно-психологические пространные размышления героев, но, представляется, что второй раз читать ее школьник вряд ли бы захотел - такими неживыми, ненастоящими, видятся подростки и их родители. Однако, есть в повести то, что М. Майофис назвала «предвестием оттепели» (Майофис, 2015: 105) - Печерникова показывает, как распространяется идея индивидуального подхода, о важности которого говорит завметодкабинетом школы, парторг и «просто мудрая женщина»: «Различные педагогические влияния формируют различные характеры. Поэтому каждый ученик требует особого подхода. Один и тот же педагогический прием может по-разному подействовать на различных учеников. В этом, если хотите, заключается диалектика воспитания. Отсюда очень важно знать каждого ученика, понимать его» (Печерникова, 1960: 95).

\section{СПИСОК ЛИТЕРАТУРЫ}

Василейский, С. (1936) Вредные теории и практика педологов // Горьковская коммуна. 2 августа. С. 2. 
Доброхотов, С. П. (1944) О научно-исследовательской тематике кафедр педагогики педагогических институтов // Советская педагогика. № 2-3.

Из протокола заседания коллегии Наркомпроса РСФСР об участии школы, семьи и общественности в воспитании детей (2017) // Школа в России в документах XX века : Сборник документов и материалов / рук. проекта А. К. Сорокин; сост. 3. Н. Вишнякова, А. Н. Максенкова, О. А. Шашкова. М. : Политическая энциклопедия. 439 с. С. 224-227.

Камолина, Е. А., Федикович, Э. В. (2017) Аркин Ефим Аронович (1873-1948) - российский психолог и педагог (К 145-летию со дня рождения) [Электронный ресурс] // Международный студенческий научный вестник. № 6. URL: http://www.eduherald.ru/ru/article/view?id=17921 (дата обращения: 11.12.2018).

Кольцова, В. А., Олейник, Ю. Н. (2006) Советская психологическая наука в годы Великой Отечественной войны (1941-1945). М. : Московский гуманитарный университет ; Институт психологии РАН. 360 с.

Корнилов, К. Н. (1946) Психология : учебник для средней школы. М. : Учпедгиз. 152 с.

Кукулин, И. (2015) «Воспитание воли» в советской психологии и детская литература конца 1940-начала 1950-х годов // Острова утопии: Педагогическое и социальное проектирование послевоенной школы (1940-1980-е). М. : Новое литературное обозрение. 720 с. С. 152-192.

Майофис, М. (2017) Как читать «Витю Малеева в школе и дома» [Электронный ресурс] // Журнал. URL: https://arzamas.academy/mag/436-nosov? (дата обращения: 17.12.2018).

Майофис, М. (2015) Предвестия «оттепели» в советской школьной политике позднесталинского времени // Острова утопии: Педагогическое и социальное проектирование послевоенной школы (1940-1980-е). М. : Новое литературное обозрение. 720 с. С. 35-106.

Моносзон, Э., Орловский, Б. (1936) Гнилые теории горьковских педологов // Горьковская коммуна. 21 июля. С. 2.

Орловский, Печерникова (1933) Инструктивно-методическое письмо об обследовании дефектов речи у детей дошкольного и школьного возраста // В помощь учителю. № 5. С. 17-23.

Печерникова, И. А. (1934а) Некоторые педологические предпосылки к проведению проверочных испытаний по математике // Горьковский просвещенец. № 1-2. С. 16-23.

Печерникова, И. А. (1934b) О проверочных вопросах (на основе изучения опыта испытаний 1934 г.) // Горьковский просвещенец. № 11-12. C. 114-119. 
Печерникова, И. А. (1935а) Опыт педологической работы // Средняя школа. № 1. С. 72-76.

Печерникова, И. (1935b) Педолого-педагогическая работа с родителями // Начальная школа. № 3. С. 14-19.

Печерникова, И. (1936а) Вспомогательные классы // Горьковская коммуна. 17 декабря. С. 3.

Печерникова, И. А. (1936b) О проверочных испытаниях прошлого (1935) года // Средняя школа. № 4. С. 9-13.

Печерникова, И. (1960) Подростки : педагогическая повесть. М. : Молодая Гвардия. 334 с.

Соколов, М. (1931) Первая рабочая педологическая конференция // Педология. № 4 (16). С. 74-78.

Теплов, Б. М. (1951) Психология : учебник для средней школы. М. : Учпедгиз. 263 с.

Хроника (1934) // Горьковский просвещенец. № 2-3. С. 133.

Дата поступления: 15.01.2019 2.

Стоюхина Наталья Юрьевна - кандидат психологических наук, доцент, доцент кафедры психологии управления Нижегородского государственного университета им. Н. И. Лобачевского. Адрес: 603000, Россия, г. Нижний Новгород, Университетский пер, д. 7. Тел.: +7 (910) 382-71-46. Эл. адрес: natast0@rambler.ru

Stoyukhina Nataliya Yurievna, Candidate of Psychology, Associate Professor, Associate Professor, Departament of Administration Psychology, Lobachevsky State University of Nizhny Novgorod. Postal address: 7, Universitetsky Lane, Nizhny Novgorod, Russian Federation, 603000. Tel.: +7 (910) 382-71-46. E-mail: natast0@rambler.ru

\section{Для цитирования:}

Стоюхина Н. Ю. Повесть бывшего педолога о подростках и военном времени [Электронный ресурс] // Научные труды Московского гуманитарного университета. 2019. № 1. URL: http://journals.mosgu.ru/trudy/article/view/935 (дата обращения: дд.мм.гг.). DOI: 10.17805/trudy.2019.1.8 